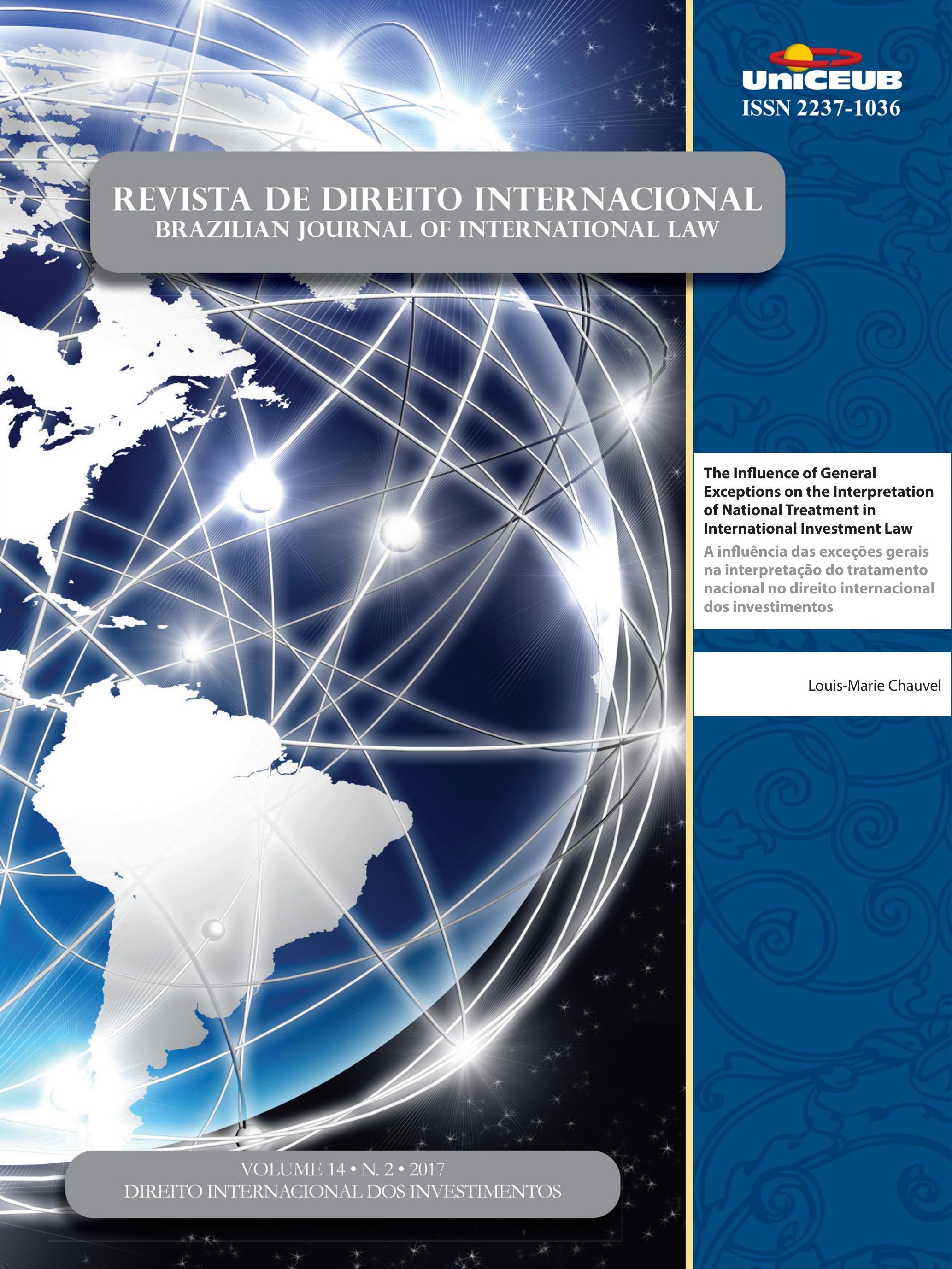




\section{Sumário}

I. Crônicas do Direito Internacional ...............................................1

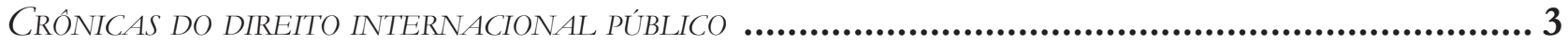

A resolução 2272 (2016) do Conselho de Segurança das Nações Unidas - O POSICIONAMENTO DA ONU FACE ÀS ALEGAÇÕES DE ABUSO E EXPLORAÇÃo SEXUAL POR SUAS

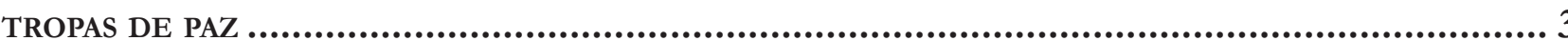

Sarah Dayanna Lacerda Martins Lima

CRÓNICAS DE DiREITo INTERNACIONAL PRIVADO...................................................................

Nadia de Araujo, Marcelo De Nardi, Gustavo Ribeiro, Fabrício Polido e Inez Lopes

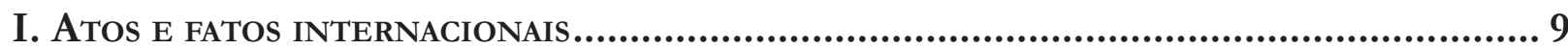

Crônica 1. Novidades de 2017 SObRE CIRCulaÇÃo faCilitada DE SENTENÇAS ESTRANGEIRAS 9

Crônica 2: O Direito Transnacional e os episódios das Carnes.........................................16

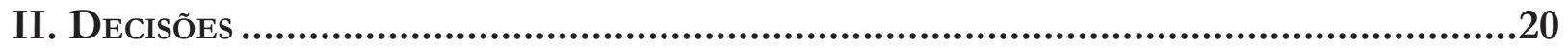

Crônica 3: A Irresistível ForÇa da ORDEM PÚblica E A HOMOLOGaÇÃo DE SENTENÇAS

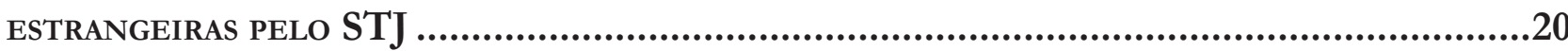

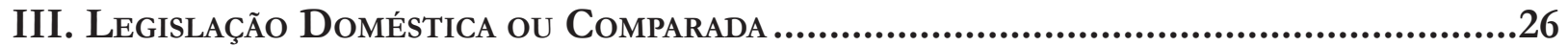

Crônica 4 - Dignidade da pessoa humana e mudança de paradigma da Lei de Migração

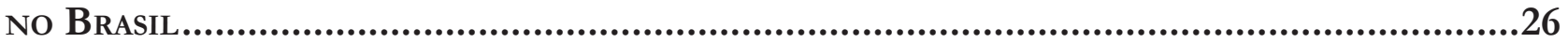

II. Dossiê especial: Direito Internacional dos InVEstimentos ................35

Non-adjudicatory State-State Mechanisms in Investment Dispute Prevention and Dispute Settlement: Joint Interpretations, Filters and Focal Points 
Mapping the Duties of Private Companies in International Investment Law .50 Nitish Monebhurrun

LA LÉGALITÉ DE L'INVESTISSEMENT DEVANT L'ARBITRE INTERNATIONAL: À LA RECHERCHE D'UN POINT D'ÉQUILIBRE .73 Hervé Ascensio

Host STATES AND STATE-STATE INVESTMENT ARBITRATION: STRATEGIES AND CHALlENGES......81 Murilo Otávio Lubamdo de Melo

Right to Regulate, Margin of Appreciation and Proportionality: Current Status in Investment Arbitration in Light of Philip Morris V. Uruguay. .95 Giovanni Zarra

Investments on Disputed Territory: Indispensable Parties and Indispensable Issues....122 Peter Tzeng

The Influence of General Exceptions on the Interpretation of National

Treatment in INTERNATIONAL INVESTMENT LAW. 140 Louis-Marie Chauvel

UMA PRoposta de REFleXão SObRe os ACFIs: Até QUE PONTO O TRATAMENTo de NAÇão MAIS FAVORECIDA PODE MINAR A ESTRATÉGIA POLÍTICA QUE OS EMBASA? 160

Michelle Ratton Sanchez Badin, Daniel Tavela Luis e Mario Alfredo de Oliveira

ECUADOR's 2017 TERMINATION OF TREATIES: HOW NOT TO EXIT THE INTERNATIONAL INVESTMENT REGIME 179

Jose Gustavo Prieto Muñoz

ONE BELT, ONE ROAD: NOVAS INTERFACES ENTRE O COMÉRCIO E OS INVESTIMENTOS INTERNACIONAIS 193

Flávio Marcelo Rodrigues Bruno e Marilda Rosado de Sá Ribeiro

III. Artigos Sobre outros TEMAS..................................................... 214

TolerânCIA E REFugIO: UM ENSAIO A PARTIR Do ACORdo EU-TurQUiA 216 Flávia Cristina Piovesan e Ana Carolina Lopes Olsen 
O TRATAMENTO do APÁtridA NA NOVA LEI DE MIGRAÇÃo: ENTRE AVANÇOS E RETROCESSOS...237 Jahyr-Philippe Bichara

O caráter humanista da Lei de Migrações: aVAnços da Lei N. 13.445/2017 E Os desafios DA REGULAMENTAÇÃO. 254 Marcelo Dias Varella, Clarice G. Oliveira, Mariana S.C. Oliveira e Adriana P. Ligiero

Reform of the United Nations Security Council: The Emperor Has No Clothes.268 Ljubo Runjic

A IDEIA DE QUe os LATINO-AMERICANOS PREFEREM O AUTORITARISMO À DEMOCRACIA À luz da reinterpretação dos Critérios do Programa das Nações Unidas para o DesenVolvimento 286

Gina Marcilio Pompeu e Ana Araújo Ximenes Teixeira

A PRoteção da ORIENTAÇÃo SEXUAL E IDENTIDAdE DE GÊNERO DIVERSAS NA CORTE PENAL internacional: Entre Realpolitiks E Os Direitos Humanos

Gustavo Bussmann Ferreira

A desnacionalização e as violações de direitos humanos na República Dominicana. 331 Daniela Menengoti Gonçalves Ribeiro e Rodrigo Ichikawa Claro Silva

CompetênCia do TPI no Caso do ATAque ao hospital de Kunduz: uma análise ENVOLVENDO A JURISDiÇÃo do TPI EM RELAÇÃO A NACIONAIS DE EsTAdOS NÃO-PARTE do Estatuto DE Roma

Filipe Augusto Silva e Renata Mantovani de Lima

A CRIMINALIZAÇÃo DOS IMIGRANTES EM SITUAÇÃo IRREGULAR NA ITÁliA: BIOPOLÍtica E DIREITO PENAL DO AUTOR.

Maiquel Angelo Dezordi Wermuth e Jeannine Tonetto de Aguiar

The New Rules On Trade And Environment Linkage In Preferential Trade Agreements

Alberto do Amaral Júnior e Alebe Linhares Mesquita

Beyond THE Border between the North and the South: towards a Decolonization of EPISTEMOLOGIES AND FIELDS OF RESEARCH ON MERCOSUR 
A aplicabilidade da Convenção de Montreal no direito brasileiro.

Aziz Tuffi Saliba e Alexandre Rodrigues de Souza

REgIME DE TRANSPARÊNCIA FISCAL NA TRIBUTAÇÃo DOS LUCROS AUFERIDOS NO EXTERIOR (CFC RULES): LACUNAS E CONFLITOS NO DIREITO BRASILEIRO

Paulo Rosenblatt e Rodrigo Torres Pimenta Cabral

As Regras Brasileiras de Tributação de Controladas e Coligadas no Exterior: verdadeiras Controlled Foreign Company (CFC) Rules? .......................................465

Melina de Souza Rocha Lukic e Amanda Almeida Muniz

O RETORNO DE BENS CULTURAIS

Aziz Saliba e Alice Lopes Fabris

Direitos culturais e Nações Unidas: uma análise a partir da Declaração Sobre a eliminação de Todas as Formas de Intolerância e Discriminação Baseadas na Religião OU NA CRENÇA

Leilane Serratine Grubba e Márcio Ricardo Staffen

OS REFLEXOS DA PROTEÇÃO INTERNACIONAL DA PROPRIEDADE INTELECTUAL PARA O DESENVOLVIMENTO INTERNO: UMA ANÁLISE SOBRE O SISTEMA PATENTÁRIO BRASILEIRO E A TRANSFERÊNCIA DE TECNOLOGIA

Michele M. Segala e Isabel Christine S. De Gregori

O CASO HIPOTÉTICO DA MORTE DO EMBAIXADOR FRANCÊS NA ESPANHA: DUAS ESPÉCIES DE IUS gentium em Francisco de Vitoria

Rafael Zelesco Barretto

De volta À BeVilaqua: anÁlise ECONÔMICA dA APLICAÇão do ART. $9^{\circ}$ DA LINDB Às OBRIGAÇÕES CIVIS CONTRATUAIS

Danielle Cristina Lanius e Ivo Teixeira Gico Jr 


\title{
The Influence of General Exceptions on the Interpretation of National Treatment in International Investment Law*
}

\author{
A influência das exceções gerais na \\ interpretação do tratamento nacional no \\ direito internacional dos investimentos
}

Louis-Marie Chauvel ${ }^{* *}$

\begin{abstract}
Recent International Investment Agreements have incorporated General Exceptions similar to GATT Article XX in order to balance the respect of National Treatment and protection of States' right to regulate. The purpose of this article is to determine if these exceptions are a suitable choice in order to achieve this objective or if another option would be preferable. We first established that General Exceptions are operative exceptions and not interpretative statements. This allowed to assess their effect on the interpretation of national treatment and we managed to prove their potentially detrimental effect on the right to regulate. Then, we searched for other means to interpret National Treatment compatible with general exceptions but none appears to be really effective in achieving the purpose to balance protection of investments and State's right to regulate. As a consequence, a final study for other treaty wording achieving the stated objective allows to conclude that the most suitable choice would be to codify selected arbitral award allowing to take into account public policy objectives to determine if two investors are in same circumstances, therefore securing the contemplated balance.
\end{abstract}

Keywords: International investment law, international investment agreements, international trade law, general exceptions, national treatment, right to regulate.

* Recebido em 31/05/2017

Aprovado em 19/08/2017

** University of Rennes 1, IODE (Institut de l'Ouest : Droit et Europe) UMR CNRS 6262 louis-marie.chauvel@univ-rennes1.fr. I thank Nnaemeka Anozie for his advice on this article and the reviewers for their precious comments. This article is a piece submitted for a LL.M. seminar on Advanced International Economic Law at the University of Ottawa, held in 2016 by Professor Nicolas Lamp.

\section{Resumo}

Os recentes acordos internacionais de investimento incorporaram exceções gerais semelhantes ao artigo XX do GATT com o intuito de equilibrar o respeito do Tratamento nacional e a proteção do direito dos Estados de regular. O objetivo deste artigo é determinar se essas exceções são uma escolha adequada para alcançar esse objetivo ou se outra opção seria preferível. Primeiro, estabelecemos que as exceções gerais são exceções operacionais e não declarações interpretativas. Isso permitiu avaliar seu efeito sobre a interpretação do tratamento nacional e conseguimos provar o seu potencial efeito prejudicial sobre o direito de regular. Logo, procuramos outros meios 
para interpretar o Tratamento Nacional de maneira compatível com as exceções gerais, mas nenhum parece ser realmente efetivo na realização do objetivo de equilibrar a proteção dos investimentos e o direito do Estado de regulamentar. Como consequência, um estudo final de outras provisões de tratados alcançando o objetivo declarado permite concluir que a escolha mais adequada seria codificar determinadas sentenças arbitrais de forma a poder levar em consideração os objetivos de políticas públicas para determinar se dois investidores estão nas mesmas circunstâncias, garantindo assim o previsto equilíbrio.

Palavras-chave: exceções gerais; direito de regular; tratamento nacional

\section{InTRODUCTION}

National Treatment (NT) has been a central piece in both the International Trade Law (ITL) and International Investment Law (IIL) systems. However, as several authors have detailed, ${ }^{1}$ this standard is applied differently in these two fields of International Law. This is due to differences in each field's law making process and the concept's respective purpose and history in each of these domains. The differences in application are also due to significant differences between Trade and Investments themselves.

IIL and ITL have different purposes and organizations. ${ }^{2}$ ITL is made to liberalize the streams of goods

1 DIMASCIO N. and PAUWELYN J. "Non-discrimination in Trade and Investment Treaties: Worlds Apart or Two Sides of the Same Coin?", 2008, vol.102, n 1 American Journal of International Law, p.48; KURTZ J., "The Use and Abuse of WTO Law in Investor-State Arbitration: Competition and its Discontents", 2009, vol. 20, n³ EJIL, p.749; DIEBOLD N., "Non-Discrimination and the Pillars of International Economic Law - Comparative Analysis and Building Coherency", Society for International Economic Law, Second Biennial Global Conference, July 8-10 2010, SIEL Working Paper No 2010/24, online, SSRN, < https://papers.ssrn.com/sol3/ papers.cfm?abstract_id=1632927> ; HOWSE R. and CHALAMISH E., "The Use and Abuse of WTO Law in Investor-State Arbitration: A Reply to Jürgen Kurtz”, 2010, vol.20 n44 EJIL, p.1087; KURTZ J. "The Use and Abuse of WTO Law in Investor-State Arbitration: Competition and its Discontents: A rejoinder to Robert Howse and Efraim Chalamish", 2010, vol. 20, n4 EJIL, p.1095; WEILER T.J., "Treatment No Less Favorable Provisions Within the Context of International Investment Law: "Kindly Please Check Your International Trade Law Conceptions at the Door.", 2014, vol.12, n 1 , Santa Clara Int'L L., p.77.

2 DIMASCIO N. and PAUWELYN J. supra note 1 at pp.53-8. and services worldwide by the exchange of tariff concessions and other provisions reducing barriers to trade. ${ }^{3}$ It is governed by a multilateral organization: World Trade Organisation (WTO). It is enforced by a multilateral mechanism, the WTO Dispute Settlement Body (DSB) which can authorize retaliation by one state on another. Disputes are therefore only State-to-State disputes. As Pauwelyn and DiMascio summarize: "the trade regime is about overall welfare, efficiency, liberalization, state-to-state exchanges of market access, and trade opportunities - not individual rights". ${ }^{4}$

Meanwhile, IIL has a different objective, it provides protection to investors that are present ${ }^{5}$ in the territory of the other contracting State. These investors can get enforcement of these protection through Investor-State Dispute Settlement (ISDS) provided for in most of the more than 3,000 International Investment Agreements (IIAs) currently in force. These arbitral mechanisms can make the host state liable for reparation if the investor has suffered losses from a breach of the protections provided for in the agreement by the host State.

Therefore, while ITL is headed to liberalize the exchange of goods and services worldwide, IIL is made to protect and give more predictability to investors from both parties by granting them rights in the territory of the other Party. These differences have consequences on NT provisions and analysis under both regimes.

Because of the differences of purpose between ITL and IIL, NT has also different objectives in each of these regimes. NT in the ITL frame has a double role $^{6}$.

3 General Agreement on Tariffs and Trade, Oct. 30, 1947, TIAS No. 1700, 55 UNTS 194 [hereinafter GATT], The Preamble of the GATT of 1947 exposes this liberalization purpose: "entering into reciprocal and mutually advantageous arrangements directed to the substantial reduction of tariffs and other barriers to trade and to the elimination of discriminatory treatment in international commerce" (para. 3), being a way to "raising standards of living, ensuring full employment and a large and steadily growing volume of real income and effective demand, developing the full use of the resources of the world and expanding the production and exchange of goods" (para. 2).

4 DIMASCIO N. and PAUWELYN J. supra note 1 at p.54.

5 In some treaties, NT also applies to investors that are seeking to invest in the host State. These treaties apply NT pre-establishment by referring to establishment and acquisition in the list of operations covered by the clause. This has been mainly found in treaties by Canada and the United States: See DOLZER R. and SCHREUER C., Principles of International Investment Law, $2^{\text {nd }}$ edition, 2012, Oxford : Oxford University Press, at p. 89.

6 DIMASCIO N. and PAUWELYN J., supra note 1, at pp.59-60 ; KURTZ J. "The Use and Abuse of WTO Law in Investor-State Ar- 
First, it prevents States from reducing the value of their tariff concessions by the use of internal restrictions. Second, it prevents protectionism, as described by the Appellate Body (AB):

"The broad and fundamental purpose of Article III is to avoid protectionism in the application of internal tax and regulatory measures. More specifically, the purpose of Article III "is to ensure that internal measures 'not be applied to imported or domestic products so as to afford protection to domestic production"”7

The purpose of NT in IIL is different. This provision is part of several protections provided to the investor. At first, it was not the most significant one. Indeed, in the 1960's, when the first IIAs were concluded, there was an opposition between developing and developed countries. The first ones, mostly importers of investments, relied on Carlos Calvo's doctrine and wanted to afford only "National Treatment" to foreign investors. ${ }^{8}$ Developed States, hence, integrated in the first BITs absolute protections as the principle of compensation for expropriation and Fair and Equitable Treatment. Their idea was that a minimum standard of treatment existed towards foreign investors, even if the host states did not provide such treatment to its own nationals. Therefore, NT was in the first place seen as a minimal protection. However, with the conclusion of IIAs between developed States since NAFTA ${ }^{9}$ and the higher level of treatment accorded to national investors in developed States, NT has become a more prominent standard and allows to create a level playing field. ${ }^{10}$

These different objectives resulted in different treaty wordings and interpretations.

IIAs usually contain a NT provision as follows:

"Each Party shall accord to investors of another Party treatment no less favorable than that it accords, in like circumstances, to its own investors with respect to the establishment, acquisition, expansion, management, conduct, operation, and sale or other disposition

bitration: Competition and its Discontents", supra note 1, at p.753. 7 Appellate Body Report, Japan- Taxes on Alcobolic Beverages (hereinafter Japan - Alcoholic Beverages II), WT/DS8/AB/R, WT/DS10/ $\mathrm{AB} / \mathrm{R}, \& \mathrm{WT} / \mathrm{DS} 11$ /AB/R, adopted November 1, 1996, at p.17. 8 CALVO C., Derecho Internacional Teorico y Practico de Europa y America, 1868.

9 North American Free Trade Agreement, Signed on December 17, 1992, Entered into force on January 1, 1994, vol. 32, ILM, p.605. 10 DIMASCIO N. and PAUWELYN J., supra note 1, at pp.67-8. of investments." 11

NT has been interpreted by arbitral tribunals through a three-step analysis. First, tribunals look for the existence of "like circumstances". While doing this analysis, most tribunals have required the national investor and the foreign investor to be in a competitive relationship. ${ }^{12}$

Second, the investor has to bring the proof that it has received a less favorable treatment than an investor in like circumstances. ${ }^{13}$

Third, if there has been a "less favorable treatment", the State has the possibility to bring the proof that the difference of treatment is justified by a legitimate policy objective. Such an objective would exclude the fact that the National Investor and the foreign one are in like circumstances and as a consequence exclude a breach of NT. ${ }^{14}$

NT in ITL is based on a different treaty language and has received a different interpretation by the $A B$ of the WTO.

NT is embodied in GATT (General Agreement on Tariffs and Trade) Article III. Article III.4 provides that:

"The products of the territory of any contracting party imported into the territory of any other contracting party shall be accorded treatment no less favourable than that accorded to like products of national origin in respect of all laws, regulations and requirements affecting their internal sale, offering for sale, purchase, transportation, distribution or use."

Contrary to the provisions present in most IIAs, Article III.1 provides for an indication on the purpose of the NT provision:

"The contracting parties recognize that internal

11 NAFTA, supra note 8, Article 1102 (1). Article 1102 (2) provides the same treatment for investments of the investors.

12 SD Myers v Canada, First Partial Award, November 13, 2000, ICSID Reports, vol.8, p.18 at para. 250; Pope and Talbot v. Canada, Award on the Merits of Phase 2, April 10, 2001, ICSID Reports, vol.7, p.102 at para. 78; Feldman v. Mexico, Award, December 16, 2002, ICSID Reports, vol.7, p.341 at para. 171; ADF v. United States, Award, January 9, 2003, at para. 155; Archer Daniels Midland v. Mexico, Award, November 21, 2007, at paras. 196-8; Corn Products v. Mexico, Decision on responsibility, January 15, 2008, at para.120.

13 Pope and Talbot v. Canada, supra note 11, at para 42 ; Feldman v. Mexico, supra note 11, at 173 ; Archer Daniels Midland, supra note 11, at para. 196.

14 Pope and Talbot, supra note 11, at para 78 ; SD Myers v Canada, supra note 11, at para 246 ; Marvin Roy Feldman v Mexico, Award, supra note 11, at para 184 ; GAMI v Mexico, Award, November 15, 2005, ICSID Report, vol.13, p.147, at para 114. 
taxes and other internal charges, and laws, regulations and requirements affecting the internal sale, offering for sale, purchase, transportation, distribution or use of products, and internal quantitative regulations requiring the mixture, processing or use of products in specified amounts or proportions, should not be applied to imported or domestic products so as to afford protection to domestic production." (emphasis added)

The interpretation has therefore been different compared to the one developed in IIL. It consists of three steps.

First, there is to identify what is the scope of "like products". This operation is based on a competitive analysis. ${ }^{15}$ The AB has rejected the possibility to take into account a legitimate objective while determining the scope of "like products". ${ }^{16}$ This is a rejection of an "aim and effect" analysis, an interpretation of "so as to afford protection" requiring an intention to discriminate from the State. ${ }^{17}$ This interpretation is based on the textual differences between Article III.2 and article III.4 and the presence of GATT Article XX General Exceptions (GE), that would have made this approach redundant. ${ }^{18}$

The "so as to afford protection" part of Article III:1 has eventually been interpreted as requiring the measure to have the effect to treat imported products less favorably than the national ones. ${ }^{19}$ This is taken into account in the second phase of the analysis: the establishment of a "less favorable treatment", by comparing the treatment accorded to the whole group of imported products to the one granted to the whole group of national products. $^{20}$

The legitimate objectives are taken into account during a third step, under GATT Article XX, that contains an exhaustive list of purposes and conditions. Such ex-

15 Appellate Body Report, European Communities - Measures Affecting Asbestos (hereinafter EC - Asbestos), WT/DS135/R, adopted April 5, 2001, at para. 99.

16 Appellate Body Report, Japan-Beverages II, supra note 6, at 27-8. 17 HUDEC, R.E. "GATT/WTO Constraints on National Regulation: Requiem for an "Aim and Effects" Test", 1998, vol.32, n³ The International Lawyer, p.619, at pp.632-3.

18 Appellate Body Report, Japan - Alcoholic Beverages, supra note 15 , at $28-31$.

19 Appellate Body Report, Korea - Measures Affecting Imports of Fresh, Chilled and Frozen Beef (hereinafter Korea - Beef), WT/ DS161/AB/R, WT/DS169/AB/R, adopted January 10, 2001, at paras. 135-7.

20 Appellate Body Report, EC - Asbestos, supra note 14, at para. 115 ceptions do not exist in IIL.

However, with the development of a growing concern about the preservation of a regulatory space for the host State, several treaties and model Bilateral Investment Treaties (BITs) have incorporated a GE clause either identical or similar to GATT ${ }^{21}$ Article XX.22 This move has been started by Canada since 1994 and incorporated in its 2004 Model BIT. ${ }^{23}$ If it is not widespread, GE have been recently included in each of the EU's IIAs ${ }^{24}$, including in its proposal for the investment chapter of the Transatlantic Trade and Investment Partnership (TTIP) ${ }^{25}$ that will serve as a pattern for its future IIAs negotiations ${ }^{26}$. This appropriation by the EU

21 Foreign Affairs and International Trade Canada (DFAIT), Canadian FIPA Model, 20 May 2004, Article 10, online, Italaw < http://www.italaw.com/documents/Canadian2004-FIPA-modelen.pdf >; Final CETA (Comprehensive Economic and Trade Agreement) Text, released February 29, 2016, online: European Commission < http://trade.ec.europa.eu/doclib/docs/2016/february/tradoc_154329.pdf $>$.

22 NEWCOMBE A., "The use of general exceptions in IIAs: increasing legitimacy or uncertainty?”, in LÉVESQUE C. and DE MESTRAL A. (eds.), Improving International Investment Agreements, 2013, New York: Routledge, p.267, at p.268.

23 LEVESQUE C., "The Challenges of 'Marrying' Investment Liberalisation and Protection in the Canada-EU CETA" in BUNGENBERG M., REINISCH A. and TIETJE C., EU and Investment Agreements - Open Questions and Remaining Challenges, Hart Publishing, 2012, p.121, at p.139.

24 EU-Singapore Free Trade Agreement - Authentic text as of May 2015, negotiations concluded 14 October 2014, online, European Commission: <http://trade.ec.europa.eu/doclib/press/index. cfm?id=961 >, Article 9.3\$3; Comprehensive Economic and Trade Agreement between Canada, of the one part, and EU and its Member States, on the other, online, European Union Council, <http:// www.consilium.europa.eu/en/press/press-releases/2016/10/28eu-canada-trade-agreement/ $>$, Article 28.3; EU-Vietnam Free Trade Agreement, Agreed text as of January 2016, online, European Commission, <http://trade.ec.europa.eu/doclib/press/index. cfm?id=1437>, Part on Trade in Services, Investment and e-Commerce, Chapter VII.

25 European Commission, Draft text of TTIP Chapter II Investments, 12 June 2015, online, European Commission, <http:/ / trade. ec.europa.eu/doclib/press/index.cfm?id=1364>, to be read jointly with the whole proposal of the Commission regarding TTIP, Chapter VII, Article 7.1.

26 European Commission, Concept paper "Investment in TTIP and beyond - the path for reform Enhancing the right to regulate and moving from current ad hoc arbitration towards an Investment Court", 12 May 2015, online, European Commission, <chromeextension://oemmndcbldboiebfnladdacbdfmadadm/http://trade. ec.europa.eu/doclib/docs/2015/may/tradoc_153408.PDF>, at p.4. For studies on the IIA model of the EU, see HERVE A., "L'Union européenne comme acteur émergent du droit des investissements étrangers : pour le meilleur ou pour le pire?", CDE, 2015, pp. 179-234; TITI C., "International Investment Law and the European Union: Towards a New Generation of International In- 
may spread such clauses, due to its growing prominent position and influence in IIL. ${ }^{27}$

In the treaties incorporating such exceptions, a new scheme is created, similar to the one existing between GATT Articles III and XX. Considering the differences between the two regimes described above, questions arise from the impact of these exceptions on the interpretation of NT in IIL, which could go against the very purpose of the inclusion of this type of provisions: balancing the governments' right to regulate and the protection of foreign investors.

To address these interrogations, this article first demonstrates that GE are operative exceptions and not interpretative statements (Part I), and that their inclusion may have consequences on the interpretation of NT in IIL, requiring to adopt mainly competitive analysis (Part II). Therefore, there is to find possibilities to interpret NT that permit to fill the gaping loophole for legitimate policy objectives (Part III). Even with these interpretations, it would be better to find other ways to achieve the same objective while drafting IIAs (Part IV).

\section{General Exceptions Are Operative EXCEPTIONS AND NOT INTERPRETATIVE Statements}

Authors have followed two different ways in discussing the consequences of the integration of GATT Article XX like Exceptions in the IIAs. On the one hand, some of them have described these as being interpretative statements that only inform the meaning of other provisions, without having much effect on NT itself. ${ }^{28}$

vestment Agreements, 2015, vol. 26, n³, EJIL, p. 639; GUICHARD-SULGER B., "Le nouveau modèle européen d'accords portant sur l'investissement étranger : Un modèle singulier et innovant?", Geneva Jean Monnet Working Paper, 2016, n²6/2016, online, CEJE, <http://www.ceje.ch/index.php/download_file/ view $/ 462 / 2714 />$.

27 DE MESTRAL A., "The Evolving Role of the European Union in IIA treaty-making", in LÉVESQUE C. and DE MESTRAL A. (eds.), Improving International Investment Agreements, 2013, New York: Routledge, p.42; TITI C., supra note 26, at p. 661; CHAUVEL L.-M., "Normative Inlfuence of the European Union in the Field of International Investment Law, 2017, forthcoming;

28 SABANOGULLARI L., 'The Merits and Limitations of General Exception Clauses in Contemporary Investment Treaty Practice', May 21 2015, Online: Investment Treaty News < https:/ /www. iisd.org/itn/2015/05/21/the-merits-and-limitations-of-generalexception-clauses-in-contemporary-investment-treaty-practice/ >,
On the other hand, some others have considered these exceptions as restricted and operative exceptions, therefore having effects on the interpretation of NT. ${ }^{29}$

We consider that GE in the shape of GATT Article XX cannot be seen as "interpretative statements". Some IIAs have incorporated interpretative statements as a way to encourage the general policy objectives to be taken into account in the application and interpretation of IIAs provisions, such as NT. For Instance, NAFTA Article 1114 (1) provides that:

"Nothing in this Chapter shall be construed to prevent a Party from adopting, maintaining or enforcing any measure otherwise consistent with this Chapter that it considers appropriate to ensure that investment activity in its territory is undertaken in a manner sensitive to environmental concerns."

This kind of interpretative statements are very different from the GE in the shape of GATT Article XX. GATT Article XX like exceptions have two specificities. First, they allow to exclude a breach of NT if the contested measure is necessary to achieve a closed list of public purposes. ${ }^{30}$ These objectives are core values taken into account otherwise in IIAs as possible exceptions to the liability of the State. Indeed, protection of health and environment are considered as "Legitimate Public Welfare Objectives" excluding the existence of an expropriation even if a regulatory measure has wholly deprived the investor of its investment. ${ }^{31}$

Second, their application is conditioned by the requirements of the "chapeau", providing:

"Subject to the requirement that such measures are not applied in a manner which would constitute a means of arbitrary or unjustifiable discrimination between countries where the same conditions prevail, or a dis-

Accessed on 29 May 2017.

29 LEVESQUE C., "Influences of the Canadian FIPA Model and the US Model BIT : NAFTA Chapter 11 and Beyond", 2006, vol.44, Can. Y.B. Int'l L., p.249; LEVESQUE C., "The Inclusion of GATT Article XX exceptions in IIAs: a potentially risky policy”, in ECHANDI E. and SAUVÉ P., eds., Prospects in International Investment Law and Policy Cambridge: Cambridge University Press, 2013, p.363; NEWCOMBE A., supra note 21.

30 For instance, Canadian FIPA Model of 2004, supra note 20, at Article 10 (1) allows "measures necessary: (a) to protect human, animal or plant life or health; (b) to ensure compliance with laws and regulations that are not inconsistent with the provisions of this Agreement; or (c) for the conservation of living or non-living exhaustible natural resources".

31 Ibid., Annex B.13(1). 
guised restriction on international trade, nothing in this Agreement shall be construed to prevent the adoption or enforcement by any contracting party of measures" 32

Therefore, it appears that, by conditioning the exceptions implemented to protect the most core objectives of Public Policy according to IIAs, it establishes a new scheme in the interpretation of NT. The provision on NT becomes the rule and the exceptions are specifically laid down in a separate provision. The difference with interpretative statements has to be found there. Interpretative statements inform the interpretation of provisions, such as NT, to take into account some policy objectives. It is still possible to interpret the provisions more broadly, to take into account other interests.

Otherwise, GE require that the interpretation given of NT do not deprive them of their utility, by making them redundant. ${ }^{33}$ Indeed, following the principle of effectiveness in treaty interpretation in International law, a treaty provision cannot be interpreted in a way that would deprive it of its utility, except if doing otherwise would go against the purpose of the treaty. ${ }^{34}$

The fact that the NT should be interpreted differently when Article XX like exceptions are incorporated in the Agreement has also been highlighted by Investment rulings. In the SD Myers award, the tribunal has found that the absence of GE in NAFTA Chapter 11 informed the way to interpret the NT provision itself. ${ }^{35}$ While incorporating these exceptions in IIAs, the State Parties knew this interpretation. Therefore, the intention of the Parties are not to consider that GE are mere informative statements but standing operative exceptions to the NT Provision.

Hence, the inclusion of GE in IIAs requires that the criteria taken into account while determining the

32 GATT, supra note 3, Article XX.

33 LEVESQUE C., "The Inclusion of GATT Article XX exceptions in IIAs: a potentially risky policy", supra note 23, at p.366.

34 DAILLIER P., FORTEAU M. and PELLET A., Droit international public, $8^{\text {th }}$ edition, 2009, Paris: LGDJ, at pp.288-289. Interpreting NT in a way that would not deprive GE of their utility and therefore restricting the possibility of taking into account legitimate policy objectives would not go against the purpose of II As, which is often stated as follows: "Recognizing that the promotion and the protection of investments of investors of one Party in the territory of the other Party will be conducive to the stimulation of mutually beneficial business activity, to the development of economic cooperation between them and to the promotion of sustainable development", for the example of the Canada Model BIT (2004), inviting to interpret exceptions narrowly.

35 SD Myers v Canada, supra note 11, at para 246. existence of a breach of NT do not have the effect to deprive them of their utility and objective in the Agreement. The analysis will then focus on the criteria taken into account by several arbitral tribunals to determine if they may deprive the GE of their useful effect.

\section{THE CONSEQUENCES ON THE INTERPRETATION of National Treatment : A Competitive Analysis of the "Same circumstances" CRITERION}

While interpreting the NT provision, an arbitral tribunal mainly takes into account three factors: legitimate policy objectives (A), nationality (B) of the investor and competitive relationship (C). The integration of GE will tend to reduce drastically the importance of the two first criteria, resulting in a mainly competitive analysis of NT.

\subsection{A Drastic Diminution of the Role of Legitimate Policy Objectives in the Determination of "Like Circumstances"}

As described earlier, in the determination of a breach of NT, Tribunals have taken into account the objective of the measure as part of the analysis of "like circumstances". Indeed, once a less favorable treatment has been shown, the burden of proof shifts. The State has then to demonstrate that this treatment is based on a "legitimate policy objective". ${ }^{36}$ This would then allow to exclude the existence of "like circumstances" between a national investor and the foreign investor. ${ }^{37}$

Tribunals have admitted a very broad range of legitimate policy objectives. In the GAMI award, the tribunal has admitted the objective of "ensuring that the sugar industry was in the hands of solvent enterprises". ${ }^{38}$ In Pope and Talbot, the relevant objective was "to implement

36 Arbitral tribunals have used different languages but have consistently taken these objectives into account: Pope and Talbot, Award on the Merits of Phase 2, supra note 11, at para 78 : « reasonable nexus to rational government policies"; SD Myers v Canada, supra note 11, at para 246 : "legitimate policy measures that are pursued in a reasonable manner"; Marvin Roy Feldman v Mexico, Award, supra note 11 , at para 184 , rely on the analysis developed by the tribunal in Pope and Talbot, GAMI v Mexico, supra note 13, at para 114: "that measure was plausibly connected with a legitimate goal of policy". 37 The whole analysis is described by the tribunal in Pope and Talbot, supra note 11, at paras 78-9.

38 GAMI v Mexico, supra note 13, at para 114. 
the SLA" 39 The SLA (Soft Lumber Agreement) was an 1996 Agreement between the United States of America (USA) and Canada to solve a trade dispute. ${ }^{40}$

Moreover, Tribunals have not required a stringent standard of effectiveness from the State concerning the means to achieve its objective. The tribunal in the GAMI case have admitted that:

"The Government may have been misguided. That is a matter of policy and politics. The Government may have been clumsy in its analysis of the relevant criteria for the cutoff line between candidates and non-candidates for expropriation. Its understanding of corporate finance may have been deficient. But ineffectiveness is not discrimination." ${ }^{41}$

This analysis of "like circumstances" in the NT provision seems to be inconsistent with the introduction of GE. As a matter of fact, a measure by a state that would have been found in breach of National Treatment interpreted this way could not meet the requirements of GATT Article XX like exceptions. Such a measure would not have been justified by any policy objective interpreted much more broadly than the closed list provided for in GATT Article XX. Moreover, it would not have met the only requirement of effectiveness described in the GAMI award: not to be per se discriminatory. Thus, it is more than unlikely that this measure could enter into the scope of the GE, as it would certainly neither pursue one of the objectives listed nor meet the requirement of "necessity" and the conditions of the chapeau. In conclusion, to take into account legitimate policy objectives under the analysis of "like circumstances" as described above would make the GE useless and would go against the principle of effectiveness in treaty interpretation as described above.

However, legitimate policy objectives could still be taken into account, although in a much more restrictive way. Lévesque suggests to rely on the decision of the $\mathrm{AB}$ in the $\mathrm{EC}-A$ sbestos case. ${ }^{42}$ In this decision, the $\mathrm{AB}$ has considered it relevant to take into account criteria such as health risk in the analysis of the existence of "like products", but only to the extent that the health risk was relevant to "[assess] the competitive

39 Pope and Talbot v Canada, supra note 11, at para 103.

40 Ibid., at para 18.

41 GAMI v Mexico, supra note 13, at para 114.

42 LEVESQUE C., "Influences of the Canadian FIPA Model and the US Model BIT : NAFTA Chapter 11 and Beyond", supra note 23 , at p. 275 . relationship in the marketplace between allegedly like products". ${ }^{43}$ Otherwise, it is taken into account in the context of GE as "a sufficient basis for "adopting or enforcing" a WTO-inconsistent measure on the grounds of human health". ${ }^{44}$ In the context of investments, this finding could be broaden from "like products" to "like circumstances". The risk affecting the competitive relationship could be due to the investment as a whole and not only to the items produced by the investor. However, the difference, for example in the polluting characteristics of the enterprise and the production, should affect the competition between a foreign investor and a national investor itself and not only require to take measures to protect the environment, such as rules on the management of specific wastes. Therefore, the line separating a health or environmental risk affecting competitive relationship and those serving as basis for a measure according to GATT Article XX like exceptions could be blurry.

To conclude, except for the circumstances where a factual differentiation is to be taken into account as affecting the competition relationship between two investors, legitimate policy objectives may not be taken into account in the determination of a breach of NT when GE are incorporated in the agreement as it would deprive those of their useful effect. Another consequence of the integration of such exceptions may be to restrain the role assigned to the nationality criterion.

\subsection{The Incertitude on the Role of Nationality}

The addition of GE questions the role of the nationality criterion in the determination of a breach of NT. Indeed, to take it into account while determining "like circumstances" would deprive these exceptions of their "effet utile" or useful effect (1) and taking it into account in the assessment of the existence of a "less favorable treatment" is ill-adapted to IIL (2).

\subsubsection{The Impossibility to take into account Nationality While Determining the Existence of "Like Circumstances".}

Most ISDS Tribunals consider the nationality of the investor as a criterion for the determination of "like cir-

43 EC-Asbestos, supra note 14, at para 115.

44 Ibid. 
cumstances". They have done so in two different ways.

First, some tribunals take the nationality of the investor into account while assessing the existence of a "legitimate policy objective". This objective is considered as a proof that the less favorable treatment lies on another basis than the nationality of the investor. ${ }^{45}$

Second, tribunals have considered that "like circumstances" would require the use of the closest national comparator available. ${ }^{46}$ That means a comparator that would be in the exact same circumstances as the foreign investor but for their nationality. ${ }^{47}$ If there is no national identical comparator, these tribunals have accepted to use the same analysis as the one described above. ${ }^{48}$

These two ways, in fact, end in the same result. Indeed, foreign investors are only found "in like circumstances" with a national investor if there is no other difference between them than their nationality.

Thus, this use of nationality is inconsistent with GE. Indeed, a measure that would have been found in breach of the NT would have imposed "less favorable treatment" to a foreign investor than to a national investor in the exact same circumstances except for their nationality. Therefore, there would be no factual basis that could justify a difference of treatment under the requirements of GATT Article XX like exceptions. For instance, it would not be possible to justify a differential treatment as necessary to protect public health if the two investors are in the exact same circumstances, the activity of one of them being no more dangerous than the activity of the other.

Therefore, this use of the criterion of nationality is

45 Pope and Talbot v Canada, supra note 11, at para 78: "Differences in treatment will presumptively violate Article 1102(2), unless they have a reasonable nexus to rational government policies that (1) do not distinguish, on their face or de facto, between foreign-owned and domestic companies."; GAMI v Mexico, supra note 13, at para 215: the analysis of the tribunal searches to determine if the difference of treatment was based on the nationality of the investors, as it concludes: "that GAMI has failed to demonstrate that the measures it invokes 'resulted from or have any connection to GAMI's participation in GAM; nor were they geared towards treating GAM in a different mode because of GAMI's participation in their social capital" knowing that GAMI was a foreign shareholder of GAM; Marvin Roy Feldman v Mexico, supra note 11, the decision relies on the findings or the Pope and Talbot award, at para 184.

46 KURTZ J., supra note 1, at pp.765-9.

47 Methanex v United States, Award, August 3, 2005, ILM, vol.44, p.1345, at para.17; Archer Daniel Midlands v Mexico, supra note XXX, at 202.

48 Ibid. not compatible with the inclusion of GATT Article XX like exceptions and two investors may be "in like circumstances" even if they have other differences than their sole nationality.

As a consequence, any difference of treatment, even if it were not based on the nationality of the foreign investor, could amount to a breach of NT. Another possible way to understand the nationality criterion would be to rely on ITL, that takes into account nationality in the analysis of the "less favorable treatment".

\subsubsection{The Role of Nationality in the Determina- tion of the Existence of a "Less Favorable Treat- ment".}

In ITL, nationality has been taken into account in a different way. Once the existence of "like products" has been identified, "a complaining Member must still establish that the measure accords to the group of "like" imported products "less favourable treatment" than it accords to the group of "like" domestic products". 49 This analysis would not make GE without object as demonstrates its use in a GATT context but it seems, however, very unsatisfactory in an IIL context in three aspects: it is based on one of the main differences between ITL and IIL NT provisions; it is not adapted to situations in which the claimant is an individual; and would also be very unsatisfactory for the host State.

First, the analysis of nationality in ITL is based on the requirements of Article III (1) that the less favorable treatment must be accorded "so as to afford protection to domestic production". ${ }^{50}$ Meanwhile, IIAs do not contain such requirement. Therefore, there is no textual basis to justify such an analysis as a requirement to find a breach of NT in IIL. ${ }^{51}$ It has been used, however, in the Corn Products case. ${ }^{52}$ As a consequence, even if this analysis is not mandated by the provision on NT, some tribunals could decide to rely on it if the nationality of the investor could not be taken into account otherwise.

Second, even if this analysis were applied, it would have many disadvantages for the investor in an IIL context because of the mere characteristics of investment

\footnotetext{
49 EC-Asbestos, supra note 14, at para 100.

50 Ibid.

51 WEILER T.J., supra note 1 at p.102; KURTZ J., supra note 1, at p.753.

52 Corn Products v Mexico, supra note 11, at paras 132 and 138.
} 
compared to trade and because the claimant is a private person.

The proof that the overall group of foreign products has been treated less favorably than the group of national products is quite easy to make. The nationality of products is determined by detailed rules of origin, and the volumes of exchanged goods is recorded by customs officials. The situation is different for investments. Indeed, once the scope of investors "in like circumstances" has been established, the investor will have to distinguish between national and foreign investors. But, the establishment of the nationality of an investor or an investment is difficult to make, as it can rely on different methodologies, as the nationality of shareholders, the incorporation of the enterprise or the place of the main seat. ${ }^{53}$

Then, the investor would have to bring the proof that the less favorable treatment has had a more important impact on foreign investors as a whole than on the group of National investors. Moreover, the question may be to know if this disproportion has to be determined on a proportion of the number of investors of each group, by a proportion of the overall production or even of the total income. These proofs also appear very difficult to make.

Furthermore, in IIL, the claims are brought by an investor and not by a State. This difference adds to the difficulties to bring the proof of a difference of treatment based on nationality in the analysis of the "less favorable treatment". Indeed, States dispose of large internal services with competence in Economy or Trade issues that make them able to conduct the type of analysis described above and necessary to bring a proof of a disproportionate impact on foreign investors or products. Moreover, as members of several International organizations, they have access to shared information, facilitating to gather the elements to prove the disproportion. ${ }^{54}$ Investors, conversely, do not have such resources and it would make it even more difficult for them to bring the required proofs.

The tribunal in the Pope and Talbot case has taken into account the preceding arguments and therefore rejected this analysis in IIL:

53 DOLZER R. and SCHREUER C., supra note 5, at p.47.

54 KURTZ J., "The Use and Abuse of WTO Law in InvestorState Arbitration: Competition and its Discontents", supra note 1, at pp.757-8.
"Simply to state this approach is to show how unwieldy it would be and how it would hamstring foreign owned investments seeking to vindicate their Article 1102 rights. Only in the simplest and most obvious cases of denial of national treatment could the complainant hope to make a case for recovery. The Tribunal is unwilling to take a step that would so weaken the provisions and objectives of NAFTA and, for the reasons stated, rejects Canada's disproportionate disadvantage test." 55

However, this approach has been followed in the Corn Products award. ${ }^{56}$ In this case, the claimant was successful to prove the existence of a breach of NT. But, the particular conditions of this case seem to amount to "the simplest and most obvious cases of denial of national treatment" referred to by the Tribunal in the Pope and Talbot award. In the case of Corn Products, the two industries, HFCS producers and Cane sugar producers were, for one, totally nationally owned and the other totally owned by foreign investors. ${ }^{57}$ Moreover, a WTO panel had found that the contentious measure was discriminatory, as it imposed a tax for the use of HFCS in soft drinks whereas such a tax did not exist for cane sugar. ${ }^{58}$ This measure was intentionally discriminatory as it was a countermeasure against the United States. ${ }^{59}$

This may have been much more difficult for the investor to prove if there had been no WTO Panel decision on discriminatory intent. In the same way, if the two industries had been partially owned by foreign and national investors, if an investor had produced both products or if an enterprise had been owned both by national and foreign shareholders, to bring a proof of a disproportionate disadvantage for the foreign investors would have been much more challenging.

Moreover, as noted by Pauwelyn and DiMascio, there would be no difference of treatment if the investor was the only foreign investor to receive less favorable treatment. He would indeed need to demonstrate that the measure affects most of the foreign investors. ${ }^{60}$

This analysis of nationality under the requirement

55 Pope and Talbot v Canada, supra note 11, at para 72.

56 Corn Products v Mexico, supra note 11, at paras 132-42.

57 Ibid., at para 132.

58 Ibid., at para 47: Mexico - Tax Measures on «Soft Drinks» and Other Beverages, WT/DS308/AB/R, released on March 6, 2006 (Report cited in the award).

59 Ibid., at para 137.

60 DIMASCIO N. and PAUWELYN J., supra note 1, at p.82. 
of a "less favorable treatment" is also unsatisfactory for the host State. In ITL, a measure that accords less favorable treatment to the group of foreign products than to the group of national like products is considered as being discriminatory. This is justified by the fact that an import of goods is considered by the states as being more "negative" and they have incentives to put barriers to reduce these imports. ${ }^{61}$ Therefore, the same analysis in IIL would mean that measures treating less favorably foreign investments than national ones, are presumed to be discriminatory treatment. However, the range of measures that apply to investors is way more important than those applied to products and as a consequence there might be a more important variety of justifications to accord a differential treatment. In addition, imports of investments are often seen as positive by the states as they provide jobs, cash flows, tax revenues, therefore it is more difficult to assume that the difference of treatment can be presumed as discriminatory. ${ }^{62}$

To take into account the nationality of the investor in the determination of "less favorable treatment" in a similar way than it is done in ITL would not deprive GE of their utility. However, there is no treaty basis to use this possibility and it would have, as described above, many side effects for both the investor and the State.

Tribunals, while taking a decision on NT in a treaty containing GE, would have a choice between two unsatisfying options as to take into account nationality as a basis for the less favorable treatment. First, they could choose not to take into account the nationality of the investor in the analysis of a breach of NT otherwise than to know if the claimant is entitled to bring a claim under the agreement. Secondly, they could take it into account in a similar way than in ITL, which reveals to have major side effects and to be ill-adapted to IIL. Therefore, the understanding of "same circumstances" should be mainly focused on a competition relationship.

\subsection{The Compatibility of a Competitive Analysis}

Although a competitive analysis between the foreign investor and its domestic comparator is not required in IIL according to treaty wording, ${ }^{63}$ it has been consisten-

61 Ibid., at 81-2.

62 Ibid.

63 KURTZ (J.), supra note 1, at p.756. tly used by arbitral tribunals while determining if investors were in "like circumstances". ${ }^{64}$

Moreover, this analysis seems in fact necessary. Indeed, when it was not used in the Occidental case, the result was inconvenient. ${ }^{65}$ The tribunal found exporters of flowers and exporters of oil as being in "like circumstances". As a consequence, a VAT refund refused to oil exporters but provided to flower or seafood exporters was found as being a "less favorable treatment" breaking NT obligation. ${ }^{66}$

Having accepted the relevance of a competitive analysis, it appears that it would not deprive GE of their useful effect. Competition is part of the analysis of NT under the GATT and has always been applied with the existence of the exceptions of GATT Article XX.

As a consequence, the inclusion of GATT Article XX like exceptions imposes changes on the analysis of NT. Legitimate policy objectives could no longer be taken into account, except in the restrictive way of EC-Asbestos. Moreover, nationality may only be taken into account in the determination of a "less favorable treatment" but this possibility appears to be very unsatisfactory in a IIL context. Therefore, the assessment of the existence of "like circumstances" would be mainly based on a competitive analysis, which could have major side effects.

\section{Finding a Way to fill the Gaping Loophole for Legitimate Policy Objectives}

A mainly competitive analysis of "like circumstances" with the only use of the GE to exclude the liability of the State would be a dramatic path for the right to regulate of the host State (A). However, an interpretation using the causation or impossibility analysis found in Dominican Republic - Cigarettes report of the AB could reduce these negative effects (B).

64 Archer Daniel Midlands v. Mexico, supra note 11, at paras. 196-8 ; Corn Products v. Mexico, supra note 11, at para.120 ; ADF v. United States, supra note 11, at para. 155 ; Feldman v. Mexico, supra note 11, at para. 171 ; SD Myers v. Canada, supra note 11, at para. 250.

65 Occidental v. Ecuador, Award, July 1, 2004, ICSID Reports, vol.12, p.156, at paras. 173-6.

66 KURTZ J. supra note 1 at pp.763-5. 


\subsection{The Mere Use of General Exceptions: A Possibly Dramatic Path for the Right to Regulate}

With the only use of a competitive analysis, the host state would have to treat all investors in the same economic sector similarly. But, contrary to products, a very broad range of regulations are applied to investors and investments. Products imported in a State are affected by regulations on the entry of products, taxation of these products, and regulations on the products. It goes differently for investments. For instance, if an investment is an enterprise incorporated in the host State it is submitted to every law applied to enterprises in the country, like labor law, tax law or corporation law. Often, these laws provide for different ways to treat the enterprises in order to pursue legitimate policy objectives, what could amount to a violation of the NT obligation under IIL.

If we take the example of a law that applies a tax rate of $15 \%$ of the revenues on enterprises which annual revenue is less important than $\$ 1,000,000$ (hereinafter referred to as case 1) and a 30\% rate to enterprises with annual revenue more important than $\$ 1,000,000$ (hereinafter referred to as case 2). In the event that two enterprises are in the same economic sector, one national in case 1 and a foreign in case 2, these two enterprises, being competitors, would be found as being "in like circumstances". But, the foreign one would get a 30\% tax rate whereas the national would get a $15 \%$ tax rate, which would amount to a "less favorable treatment" of the foreign investment and, consequently, to a breach of NT.

Therefore, in order to avoid being found in breach of NT, host States will have to organize their law regimes by economic sector as differences based on other criteria may result in a potential breach of NT, except for the laws pursuing one of the objectives of the GE and respecting the conditions of "necessity" and of the 'chapeau' of Article XX like exceptions.

In fact, the list of objectives which a measure can pursue under GATT Article XX is a very restrictive one, as it allows measures:

- To protect public morals

- to protect human, animal or plant life or health;

- relating to the importations or exportations of gold or silver;

- to secure compliance with laws or regulations which are not inconsistent with the provisions of this Agreement, including those relating to customs enforcement, the enforcement of monopolies operated under paragraph 4 of Article II and Article XVII, the protection of patents, trade marks and copyrights, and the prevention of deceptive practices;

- measures relating to the products of prison labour;

- imposed for the protection of national treasures of artistic, historic or archaeological value;

- the conservation of exhaustible natural resources if such measures are made effective in conjunction with restrictions on domestic production or consumption;

- undertaken in pursuance of obligations under any intergovernmental commodity agreement which conforms to criteria submitted to the CONTRACTING PARTIES and not disapproved by them or which is itself so submitted and not so disapproved;

- restrictions on exports of domestic materials necessary to ensure essential quantities of such materials to a domestic processing industry during periods when the domestic price of such materials is held below the world price as part of a governmental stabilization plan; Provided that such restrictions shall not operate to increase the exports of or the protection afforded to such domestic industry, and shall not depart from the provisions of this Agreement relating to non-discrimination; ${ }^{67}$

This list of objectives is indeed much more stringent than the objectives that have been taken into account in several arbitral decisions. ${ }^{68}$ Even in the frame of ITL, it has been considered restrictive, although it is used to excuse differences of treatment for a much smaller ran-

67 This list is extracted from GATT Artcle XX.

68 See the examples listed supra p.6. 
ge of measures. ${ }^{69}$ However, this article could be interpreted a bit more broadly than in the context of trade law. Indeed, in ITL, the difference of treatment allowed under Article XX must be based on the product. That is to say, the product itself must present a health risk or endanger the preservation of natural resources, excluding health risk or consequences on animal life, for example, due to production methods. ${ }^{70}$ In the context of IIL, NT is imposed to "establishment, acquisition, expansion, management, conduct, operation, and sale or other disposition of investments". ${ }^{71}$ Therefore, a difference of treatment could be justified not only because of an health or environmental risk created by the end product but because the way the investment operates presents more risks for environment or health than a national investor in "like circumstances". This would be, for instance, the case of two investors in "like circumstances" creating similar products, if one presents risks of contamination of water supplies and not the other, due to the way the two factories proceed.

However, even if a measure were justified in the light of the objectives listed in the GE, it would still have to meet the requirements of 'necessity' and the ones of the 'chapeau'.

Some treaties have extensively incorporated GAT'T article XX. ${ }^{72}$ Conversely, others have adapted it. In the first case, measures must be "relating to" some of the objectives and necessary to protect others. Contrary to this, Canadian FIPA model has imposed a requirement of necessity for all the purposes of the GE, even when the GATT only requires these to "relate to" the objective. ${ }^{73}$ The interpretation of "relating to" might be quite close to the requirement used by ISDS tribunals of a "reasonable nexus" 74 or "reasonable manner" 75 or "rational justification"76.

It is different for the necessity test. It has been first interpreted by the $\mathrm{AB}$ in the Korea - Beef case. It has required, on its face, a cost-benefits analysis, demanding "a

69 ZHOU W., 'US - Clove Cigarettes and US - Tuna II (Mexico): Implications for the Role of Regulatory Purpose under Article III:4 of the GAT'T' (2012) 15: 4 Journal of International Economic Law 1075 , at 1112 .

70 HUDEC R.E., supra note 16, at p.624.

71 NAFTA, supra note 10, article 1105.

72 Final CETA text, supra note 20, article 28.3 (2).

73 Canada FIPA Model (2004), supra note 20, article 10.

74 Pope and Talbot v. Canada, supra note 11, at para.78.

75 SD Myers v. Canada, supra note 11, at para.246.

76 Feldman v. Mexico, supra note 11, at para. 170. process of weighing and balancing a series of factors which prominently include the contribution made by the compliance measure to the enforcement of the law or regulation at issue, the importance of the common interests or values protected by that law or regulation, and the accompanying impact of the law or regulation on imports or exports". ${ }^{77}$ At the same time, it recognised that the State was free to fix its own level of protection. ${ }^{78}$ Regan points the contradiction of these two requirements and explains that the real test is not a mere 'cost-benefits' analysis, which would require to weigh the purpose of the measure with its consequences on trade, allowing the tribunal to reject the very purpose of the measure. ${ }^{79}$

According to Regan, the analysis is rather different. ${ }^{80}$ The panel accepts the level of protection required by the State but searches for alternative possibilities to achieve the same objective with less restriction on trade, except if the administrative costs of the alternatives appears to be unreasonable for the State. ${ }^{81}$ Regan notes that this approach has been consistently used by the $\mathrm{AB}$ in the cases of EC - Asbestos ${ }^{82}$, US - Gambling ${ }^{83}$ and Dominican Republic-Cigarettes ${ }^{84} .{ }^{85}$

As a consequence, any measure by the host State resulting in a difference of treatment between a national and a foreign investor in the same economic sector would have to be no more restrictive than necessary to achieve its objective in order not to constitute a breach of NT.

In addition, a measure would also have to meet the requirements of the 'chapeau' of GATT article XX. Therefore, it must "not [be] applied in a manner which would constitute a means of arbitrary or unjustifiable discrimination between countries where the same conditions prevail, or a disguised restriction on international trade". This has been interpreted in the Brazil-Retreated

\footnotetext{
77 Korea-Beef, supra note 18, at para. 164.

78 Ibid., at para 176.

79 REGAN D.H., 'The Meaning of 'Necessary' in GATT Article XX and GATS Article XIV : the myth of cost-benefit balancing',2007, vol.6, n³, World Trade Review, p.347 at p.348.

80 Ibid. at pp.348-9.

81 Korea-Beef, supra note 18, at paras. 180-2.

82 EC-Asbestos, supra note 14,

83 Appellate Body Report, United States - Measures Affecting the Cross-Border Supply of Gambling and Betting Services, WT/DS285/ AB/R, adopted April 20, 2005.

84 Appellate Body Report, Dominican Republic - Measures Affecting the Importation and Internal Sales of Cigarettes, WT/DS302/AB/R, adopted May 19, 2005.

85 REGAN D.H., supra note 72 , at p.350.
} 
Tyres case. ${ }^{86}$ In this case, Brazil imposed a ban on the importation of retreated tyres to prevent health risks. The measure presented two exceptions, one allowing the importation of these tyres from other countries of the MERCOSUR, to comply with MERCOSUR rules, another allowing Brazilians to retreat imported used tyres. ${ }^{87}$ The $A B$ found that these exceptions were "means of arbitrary and unjustifiable discrimination" because the rationales given for the exceptions were not related to the general objective of the measure. ${ }^{88}$ As a consequence, any exception to the measure that would treat differently investors would have to be justified by the very purpose of the measure.

This could be very problematic if this path was followed in the context of investments as laws taken by the host state often take into account various objectives. For example, tax laws often receive exceptions in order to serve as an incentive for economic actors to adopt certain behaviors, making it difficult to be consistent with the conditions imposed by the 'chapeau'.

As a consequence, for a measure to be consistent with the NT clause, it would have to treat all investors of the same economic sector similarly. If these were treated differently, the difference would have to be necessary to pursue one of the objectives listed in the GE, meaning that no alternative less restrictive for the foreign investor would be reasonably available. Moreover, any exception or derogation to the measure should be justified by a rationale relating to the objective of the measure itself. Hence, it would be very difficult for a measure by the host state to stick to the line of compliance with NT provision. Moreover, in ITL a State found in breach of NT only has to ensure compliance in the future, while in IIL, the State would be liable to provide a reparation to the investor, thus making it impossible to experiment measures to find if they are consistent with the GE and NT. This may result in more regulatory chill. ${ }^{89}$ However, ISDS tribunal could use the causation or impossibility analysis in order to make the interpretation of NT more protective of the Right to regulate of the State.

86 Panel Report, Brazil-Measures Affecting Imports of Retreated Tyres (hereinafter Brazil - Retreated Tyres), WT/DS332/R, Appellate Body Report, WT/DS332/AB/R, adopted December 17, 2007.

87 ZHOU W., supra note 62, at p.1098.

88 Brazil-Retreated Tyres, Appellate Body Report, supra note 80.

89 DIMASCIO N. and PAUWELYN J., supra note 1, at p.81.

\subsection{Using Causation or Impossibility Analysis: Relying on Dominican Republic - Cigarettes}

According to the reasoning exposed in the previous development, the example of the differential tax between small and bigger businesses given earlier would be in breach of NT. The purpose, to adapt the amount of taxes to the capacity to contribute of each enterprise, is not covered by the list of purposes of GAT'T Article XX.

However, by relying on the findings of the $\mathrm{AB}$ in Dominican Republic - Cigarettes ${ }^{90}$, it could be possible to develop an analysis that would avoid some of the drawbacks caused by the mere use of GE.

In this case, Dominican Republic imposed a bond of the same amount to every producers and importers of cigarettes. Among other arguments to challenge the measure on the ground of NT. Honduras advanced that National Producers had more shares of the market than foreign importers, making the per-unit amount of the bond heavier for imported cigarettes than for nationally produced, and resulting in a "less favorable treatment" of imported cigarettes. ${ }^{91}$ The $\mathrm{AB}$ rejected this allegation on the basis that the difference in treatment was only "explained by the fact that the importer of Honduran cigarettes has a smaller market share than two domestic producers". 92

Zhou suggest two interpretations of this finding. ${ }^{93}$ First, this could be seen as a causation analysis implying that "a case of less favorable treatment would be established as long as a contested measure itself is found to be responsible for an alleged disparate impact", excluding less favorable treatment merely due to the facts of the case. ${ }^{94}$ Using this analysis could exclude the breach of NT by the taxation measure given as an example above. Indeed, the differential treatment is not created by the measure itself but by the fact that the foreign investor has more important revenues than the national one.

Second, it could be seen as an impossibility analysis. It would mean that a difference of treatment would be contrary to NT in the event that the foreign investor could never get the better treatment accorded to the

\footnotetext{
90 Dominican Republic - Cigarettes, supra note 78.

91 Ibid., at para. 96.

92 Ibid.

93 ZHOU W., supra note 62, at pp.1087-8.

94 Ibid.
} 
national one. ${ }^{95}$ This would also exclude the breach in the former example. The foreign investor could get the same treatment as the national investor as soon as its annual revenue would be less important than $\$ 1,000,000$. Conversely, the national investor could get the same treatment as the foreign investor if its revenue rose above the same bar. This could be a way to exclude breaches of NT when the State applies general measures providing differential treatments on the basis of factual differences as soon as the factual conditions of the investor are susceptible to evolve, making it to be treated differently.

However, there are some reasons to think that this test would possibly not be applicable to the example given and to IIL more generally.

First, in the Dominican Republic - Cigarettes case, the measure of the State did not create any category and the difference of treatment was merely due to a factual difference. Therefore, the test established by the $\mathrm{AB}$ could be not applicable to measures creating different categories, even if these are based on mere factual differences.

Second, the analysis is based on the 'so as to afford protection to domestic production' provision of GATT Article III:1 as interpreted by the AB in the EC-Asbes$\operatorname{tos}^{96}$ and the necessity of a detrimental effect on the conditions of competition of the national investor in Korea - Beef cases $^{97} .98$ The conclusion of the analysis was that, as the difference of treatment resulted from factual differences, the difference of the bond per-unit did "not depend on the foreign origin of the imported cigarettes". ${ }^{99}$ However, as explained above, ${ }^{100}$ NT in IIL does not provide such "so as to afford protection" language and therefore does not require the difference of treatment to be based on nationality, what could exclude the use of the causation or impossibility analysis, which purpose is to demonstrate that the difference of treatment is not linked to the nationality of the investor.

Therefore, the mere use of GE may have major detrimental effects in the frame of IIL, reducing drastically the right to regulate of the State without being

95 Ibid., at 1088.

96 EC-Asbestos, supra note 14, at para. 100.

97 Korea-Beef, supra note 18, at para. 137.

98 Dominican Republic-Cigarettes, supra note 78, at paras. 91-92, 96.

99 Ibid., at para. 96.

100 See supra The Incertitude on the Remaining Role of Nationality, p.7. found liable for a breach of NT, conversely to its objective. However, there may be other ways to draft IIAs to pursue the same objective, without the risk to experience the detrimental effects described above.

\section{Finding Better Ways to Achieve the Same Objective}

In order to find better ways to achieve the same objective than the inclusion of GATT Article XX exceptions in IIAs, there is to determine exactly this objective (A). Two possible ways are to use the analysis developed under the Agreement on Technical Barriers to Trade (TBT Agreement ${ }^{101}$ (B) or to codify some selected arbitral awards (C).

\subsection{The Objective of GATT Article XX like Exceptions: Balancing Regulatory and Investor's Interests}

The inclusion of GE serves a couple of objectives: ${ }^{102}$ First, to provide written exceptions so as to avoid that an arbitral tribunal would only base a breach of NT clause on the fact that a foreign investor has received "less favorable treatment" than a national "in like circumstances" without taking into account any legitimate policy objective that would justify the measure. ${ }^{103}$

A second objective is also to establish precisely the balance between the interests of the investor and the need to pursue legitimate policy objective through the requirements of necessity and the conditions of the 'chapeau', avoiding the risk that legitimate policy objectives would be accepted too broadly.

But, as described above, the use of GE may be far too stringent for a State's right to regulate, and therefore detrimental to the first objective. Nonetheless, the establishment of this balance between the right to regulate of the States and the protection of investors is a subject of major importance and must preferably be determi-

101 Agreement on Technical Barriers to Trade, 1868 U.N.T.S. 120 (referred to as TBT Agreement).

102 NEWCOMBE A., supra note 21, at p.268.

103 For example, the tribunal in Corn Products v. Mexico, supra note 11, considered that it did not have to search for a legitimate policy objective that could have justified the difference of treatment., at para. 142. 
ned in the treaties than by arbitrators. ${ }^{104}$ It is therefore necessary to find other ways to achieve this objective.

\subsection{Analysis of "less favorable treatment" under TBT Agreement}

A first way to protect a broad range of public policy objectives while balancing the interests of both the investors and the host State could be to import in BITs the NT clause of TBT article 2:

\begin{abstract}
"2.1. Members shall ensure that in respect of technical regulations, products imported from the territory of any Member shall be accorded treatment no less favourable than that accorded to like products of national origin and to like products originating in any other country.

1.2. Members shall ensure that technical regulations are not prepared, adopted or applied with a view to or with the effect of creating unnecessary obstacles to international trade. For this purpose, technical regulations shall not be more trade-restrictive than necessary to fulfil a legitimate objective, taking account of the risks non-fulfilment would create."
\end{abstract}

This provision has been interpreted by the $\mathrm{AB}$ in the cases US - Clove Cigarettes ${ }^{105}$ and US - Tuna $I I^{106}$. In the US-Clove Cigarettes case, the $\mathrm{AB}$ differentiated the analysis of NT under the TBT agreement from the one developed under GATT.

It first established that the analysis of "like products" only serves to determine "the scope of products that should be compared to establish whether less favorable treatment is being accorded to imported products", therefore not changing the analysis from the one developed under GATTT Article III:4. ${ }^{107}$

Nevertheless, the $A B$, relying on the linkage between article 2.1 and article 2.2 and the preamble of the TBT agreement considered that a legitimate objective should be taken into account to determine if the imported product has received less favorable treatment. It considered that article 2.2 accords the possibility to create obstacles to international trade if these are "not $[\ldots]$ more trade restrictive than necessary to fulfil a legitimate policy

104 DIEBOLD N., supra note 1, at p. 15.

105 Appellate Body Report, United States - Mesures Affecting the Production and Sale of Clove Cigarettes (hereinafter US - Clove Cigarettes), WT/DS406/AB/R, Adopted April 24, 2012.

106 Appellate Body Report, United States - Measures Concerning the Importation, Marketing and Sale of Tuna and Tuna Products (hereinafter US-Tuna 2), WT/DS361/AB/R, Adopted June 13, 2012.

107 US - Clove Cigarettes, supra note 98, at para. 116. objective". As a consequence, if the analysis of differential treatment did not take into account the legitimate objective and forbid any less favorable treatment, article 2.2 would be deprived of its effet utile. ${ }^{108}$ Also taking into account the preamble of the agreement ${ }^{109}$ and the context given by other WTO Agreements ${ }^{110}$, the $\mathrm{AB}$ concluded that the less favorable treatment under TBT should be considered through a two-stage analysis. First, there is to search for a less favorable treatment of the group of imported products, compared to the one accorded to the group of national products. Second, there is to "analyze whether the detrimental impact on imports stems exclusively from a legitimate regulatory distinction rather than reflecting discrimination against the group of imported products". ${ }^{111}$ In the event that legitimate objective would justify the measure, it would have to respect the conditions of article 2.2. The same analysis was followed by the AB in US - Tuna II. ${ }^{112}$

In its reports, the $\mathrm{AB}$ has also interpreted the meaning of the necessity requirement of Article 2.2. It has retained an interpretation consistent with the one developed under GATT, ${ }^{113}$ considering the liability would be excluded if a less-restrictive, reasonably available alternative that would make an equivalent contribution to the objective, as described above. ${ }^{114}$ Moreover, it stated that the burden of proof is on the claimant, who has to bring a prima facie proof that the measure is not necessary to achieve its objective by proposing an alternative consistent with the criteria detailed above ${ }^{115}$. If the claimant succeeds to bring that proof, the burden shifts to the respondent to prove that the measure is necessary, by demonstrating "for example, that the alternative measure identified by the complainant is not, in fact, "reasonably available", is not less trade restrictive, or does not make an equivalent contribution to the achievement of the relevant legitimate objective." 116

Using this treaty language while drafting NT provisions of IIAs would allow to meet the two objectives that have driven States to use GATT Article XX like exceptions without experiencing most of the side effects

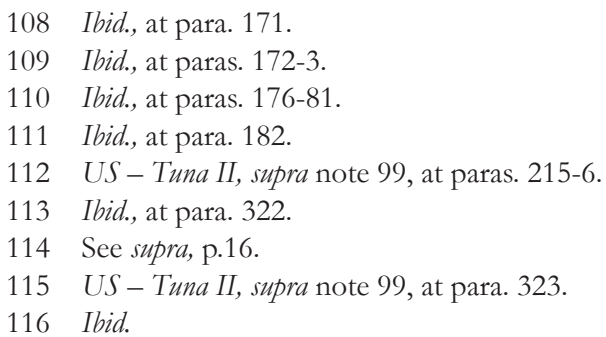


described in this paper.

First, it would require for the tribunals to consider legitimate policy objectives justifying differences in treatment using an open list of examples. This would make possible to take into account more policy objectives than GATT Article XX exceptions. Second, the requirement of "necessity" would create more balance between the right to regulate and the investors' interests than the simple requirement of a "reasonable nexus to legitimate policy objective". ${ }^{117}$

The requirement of necessity has been accepted by the States that have added GE to their IIAs as it is also a part of the analysis of GATT Article XX. Nevertheless, it seems to be an unsatisfying requirement for both the investor and the host State. ${ }^{118}$

As described above ${ }^{119}$, States have different administrations with different competences and knowledge, important resources and have access to information from International organizations. Therefore, it is manageable for them to bring the proof that a measure is not necessary to achieve the legitimate objective by providing an example of a less restrictive, reasonably available measure that makes the same contribution to the objective. This task would be much more difficult for an investor. Indeed, investors are private actors whose daily activity is not to draft regulations. They do not have the administrations' expertise to settle if a proposed measure achieves the same objective, or the information provided by International organizations. Moreover, they do not have statistic services and data in order to establish that the cost of a proposed measure would not be so high that it would not make it reasonably available. As a consequence, they would have to hire a lot of experts, making the cost of an arbitration much higher, and could still lack information that only States can obtain.

This would be also problematic for the State. Indeed, the requirement of "necessity" provides a stringent standard of review to the arbitrators. Every regulation that would differentiate between a national and a foreign investor would have to be no more restrictive than what is necessary to achieve its legitimate objective. This is problematic as it would be required for the very broad range of rules applied to investors. Moreover, if

117 Pope and Talbot v. Canada, supra note 12, at para. 78.

118 DIEBOLD N., supra note 1, at p. 22; LEVESQUE C., supra note 23 , at p.143.

119 See supra p.10 a State failed to prove the measure is indeed necessary, it would be found directly liable for a reparation.

As a consequence, if this possibility would permit the first objective described above to be achieved, the way to respond to the second one would be very unsatisfying for both the host State and the investor. Thus, it is preferable to find a third way.

\subsection{Codification of Selected Arbitral Awards}

A way to achieve the objective of the inclusion of GAT'T Article XX like exceptions is to codify relevant arbitral awards while drafting the treaty, in order to make sure that the tribunals take into account the legitimate objectives justifying differences of treatment. This is the choice that has been made in the Trans - Pacific Partnership Agreement (TPP) through the endnote 14, enlightening the interpretation of Article 9.4 (NT):

"For greater certainty, whether treatment is accorded in "like circumstances" under Article 9.4 (National Treatment) or Article 9.5 (Most-Favoured-Nation Treatment) depends on the totality of the circumstances, including whether the relevant treatment distinguishes between investors or investments on the basis of legitimate public welfare objectives". ${ }^{120}$

This solution achieves the first objective described earlier without side effects, as it has been developed in an IIL context, taking into account its specificities.

To answer to the second objective, it would be possible to modify the outcome of decisions by incorporating a more stringent standard of review than the requirement of a "reasonable nexus" but less restrictive than "necessity". This could be, for instance, manifest disproportion. Thus, the State would have the possibility to treat a foreign investor less favorably if it is justified by a legitimate objective, except if the consequences on the foreign investor are manifestly disproportionate compared to the objective. It is possible to take the example of a measure forbidding totally a production method used by a foreign investor in order to prevent a health risk whereas the one used by a national investor

120 Trans-Pacific Partnership, legally verified text, released January 26, 2016, online: New Zealand Foreign Affairs and Trade < https://www.mfat.govt.nz/en/about-us/who-we-are/treaty-making-process/trans-pacific-partnership-tpp/text-of-the-trans-pacificpartnership/ >, footnote 14 . 
would still be accepted. It would be manifestly disproportionate if minor adaptations of the process would have permitted to protect health in the same way.

Therefore, the State would have much more leeway to regulate without being found responsible and the investor would have less difficulty to bring a proof, due to the obviousness of such a breach.

\section{Final conclusions}

GE have been incorporated in a limited, but growing, number of IIAs in order to set a necessary balance between regulatory purposes and protection of foreign investors. They do so by establishing an exhaustive list of legitimate objectives and the nexus between a measure and the said objectives. However, incorporating such exceptions may drive ISDS tribunals to distance themselves from what has become a dominant practice. Indeed, GE are operative exceptions. Hence, the principle or effectiveness in treaty interpretation may require that these exceptions are not deprived of their useful effect by the interpretation of NT.

If this path was followed by ISDS tribunals, it could have detrimental effects for the right to regulate of the States. First, it would no longer be possible to take into account legitimate policy objectives in the determination of "like circumstances". Second, nationality could only be taken into account whether through a "disproportionate disadvantage test" that is ill-adapted to the IIL context or to identify a comparator. Therefore, NT would be interpreted as forbidding any less favorable treatment imposed to a foreign investor compared to a national one in the same economic sector.

Then, GE would be the only possibility to excuse a breach of NT to take into account a regulatory purpose. This solution presents two detrimental effects. First, the purposes listed at GATT Article XX are two restrictive in the IIL context. Second, the requirement of "necessity" and of the chapeau are too stringent. Moreover, no convenient interpretation pathway may allow to exclude these detrimental effects.

Thus, the most convenient way to achieve the objective followed by the integration of GE in IIAs without the risk of such detrimental effects is to develop a treaty wording that would rely on solutions developed in the
IIL framework. This could take the form of a clause inviting to take into account the regulatory purpose in the determination of "like circumstances". While drafting this clause, the parties would have the possibility to detail the understanding of a regulatory purpose and establish a nexus between the measure and the objective more adapted to IIL than the "necessity" one.

More broadly, this example invites to question the appropriateness of importing solutions developed in ITL in IIL, due to the core differences between these two fields of International economic law.

\section{References}

\section{Bibliography}

\section{Books}

CALVO C., Derecho Internacional Teorico y Practico de Europa y America, 1868.

DAILLIER P., FORTEAU M. and PELLET A., Droit international public, $8^{\text {th }}$ edition, 2009, Paris: LGDJ.

DOLZER R. and SCHREUER C., Principles of International Investment Law, $2^{\text {nd }}$ edition, 2012, Oxford: Oxford University Press.

\section{Book Chapters}

DE MESTRAL A., "The Evolving Role of the European Union in IIA treaty-making", in LÉVESQUE C. and DE MESTRAL A. (eds.), Improving International Investment Agreements, 2013, New York: Routledge, p.42.

LEGUM B. and PETCULESCU I., "GATT Article XX and International Investment Law" in ECHANDI E. and SAUVÉ P. (eds.), Prospects in International Investment Law and Policy, Cambridge: Cambridge University Press, 2013, p.340.

LEVESQUE C., “The Challenges of 'Marrying' Investment Liberalisation and Protection in the CanadaEU CETA" in BUNGENBERG M., REINISCH A. and TIETJE C., EU and Investment Agreements - Open Questions and Remaining Challenges, Hart Publishing, 2012, p.121.

LEVESQUE C., "The Inclusion of GATT Article 
XX exceptions in IIAs: a potentially risky policy", in ECHANDI E. and SAUVÉ P. (eds.), Prospects in International Investment Law and Policy, Cambridge: Cambridge University Press, 2013, p.363.

NEWCOMBE A., "The use of general exceptions in IIAs: increasing legitimacy or uncertainty?”, in LÉVESQUE C. and DE MESTRAL A. (eds.), Improving International Investment Agreements, 2013, New York: Routledge, p.267.

\section{Papers}

CHAUVEL L.-M., "Normative Inlfuence of the European Union in the Field of International Investment Law, 2017, forthcoming .

DIEBOLD N., "Non-Discrimination and the Pillars of International Economic Law - Comparative Analysis and Building Coherency", Society for International Economic Law, Second Biennial Global Conference, July 8-10 2010, SIEL Working Paper No 2010/24, online, SSRN, < https://papers.ssrn.com/sol3/papers. cfm?abstract_id $=1632927>$.

DIMASCIO N. and PAUWELYN J. "Non-discrimination in Trade and Investment Treaties: Worlds Apart or Two Sides of the Same Coin?", 2008, vol.102, n 1 American Journal of International Law, p.48

GAGLIANI G., "The Interpretation of General Exceptions in International Trade and Investment Law: Is a Sustainable Development Interpretive Approach Possible?", 2015, vol. 43, n²4, Denver Journal of International Law and Policy, p. 559.

GUICHARD-SULGER B., "Le nouveau modèle européen d'accords portant sur l'investissement étranger : Un modèle singulier et innovant?", Geneva Jean Monnet Working Paper, 2016, n²6/2016, online, CEJE, <http://www.ceje.ch/index.php/download_file/ view/462/2714/>.

HERVE A., "L'Union européenne comme acteur émergent du droit des investissements étrangers : pour le meilleur ou pour le pire?", CDE, 2015, pp. 179-234.

HOWSE R. and CHALAMISH E., "The Use and Abuse of WTO Law in Investor-State Arbitration: A Reply to Jürgen Kurtz”, 2010, vol. 20, nº 4 EJIL, p. 1087.

HUDEC, R.E. "GATT/WTO Constraints on National Regulation: Requiem for an "Aim and Effects" Test",
1998, vol.32, n³ The International Lawyer, p.619.

KURTZ J., "The Use and Abuse of WTO Law in Investor-State Arbitration: Competition and its Discontents”, 2009, vol.20, n³, EJIL, p.749.

KURTZ J. "The Use and Abuse of WTO Law in Investor-State Arbitration: Competition and its Discontents: A rejoinder to Robert Howse and Efraim Chalamish", 2010, vol. 20, n² EJIL, p.1095.

LEVESQUE C., "Influences of the Canadian FIPA Model and the US Model BIT: NAFTA Chapter 11 and Beyond”, 2006, vol.44 Can. Y.B. Int'l L., p.249.

REGAN D.H., 'The Meaning of 'Necessary' in GAT'T Article XX and GATS Article XIV: the myth of costbenefit balancing', 2007, vol.6, n³, World Trade Review, p.347.

SABANOGULLARI L., "The Merits and Limitations of General Exception Clauses in Contemporary Investment Treaty Practice', May 21 2015, Online: Investment Treaty News < https://www.iisd.org/ $\operatorname{itn} / 2015 / 05 / 21 /$ the-merits-and-limitations-of-general-exception-clauses-in-contemporary-investment-treaty-practice/ $>$.

TITI C., "International Investment Law and the European Union: Towards a New Generation of International Investment Agreements, 2015, vol. 26, n³, EJIL, p. 639.

WEILER T.J., "Treatment No Less Favorable Provisions Within the Context of International Investment Law: "Kindly Please Check Your International Trade Law Conceptions at the Door.", 2014, vol.12, n¹, Santa Clara Int'L L., p.77.

ZHOU W., 'US - Clove Cigarettes and US - Tuna II (Mexico): Implications for the Role of Regulatory Purpose under Article III:4 of the GATT', 2012, vol.15, nº 4, Journal of International Economic Law, p.1075.

\section{International Instruments}

\section{Treaties}

General Agreement on Tariffs and Trade, Oct. 30, 1947, TIAS No. 1700, 55 UNTS 194.

North American Free Trade Agreement, Signed on December 17, 1992, Entered into force on January 1, 1994, 
32 ILM 605.

Agreement on Technical Barriers to Trade, 1868 U.N.T.S. 120.

\section{Treaty projects}

EU-Singapore Free Trade Agreement - Authentic text as of May 2015, negotiations concluded 14 October 2014, online, Europan Commission: <http://trade. ec.europa.eu/doclib/press/index.cfm?id=961>

EU-Vietnam Free Trade Agreement, Agreed text as of January 2016, online, European Commission, <http:// trade.ec.europa.eu/doclib/press/index.cfm?id=1437>,

Trans-Pacific Partnership, legally verified text, released January 26, 2016, online: New Zealand Foreign Affairs and Trade < https://www.mfat.govt.nz/en/about-us/ who-we-are/treaty-making-process/trans-pacific-partnership-tpp/text-of-the-trans-pacific-partnership/ > .

Final CETA (Comprehensive Economic and Trade Agreement) Text, released February 29, 2016, online: European Commission < http://trade.ec.europa.eu/ doclib/docs/2016/february/tradoc_154329.pdf >.

\section{National instruments/National Model BITs}

\section{Model BITs}

Foreign Affairs and International Trade Canada (DFAIT), Canadian FIPA Model, 20 May 2004, Article 10, online, Italaw < http://www.italaw.com/documents/Canadian2004-FIPA-model-en.pdf $>$.

European Commission, Draft text of T'TIP Chapter II Investments, 12 June 2015, online, European Commission, <http://trade.ec.europa.eu/doclib/press/index. cfm?id=1364>

\section{Rulings}

\section{WTO Dispute Settlement}

Appellate Body Report, Japan- Taxes on Alcoholic Beverages, WT/DS8/AB/R, WT/DS10/ AB/R, \& W'T/DS $11 / \mathrm{AB} / \mathrm{R}$, adopted November 1, 1996.

Appellate Body Report, Korea - Measures Affecting Imports of Fresh, Chilled and Frozen Beef , WT/ DS161/AB/R, WT/DS169/AB/R, adopted January
10, 2001.

Appellate Body Report, European Communities - Measures Affecting Asbestos, WT/DS135/R, adopted April 5, 2001.

Appellate Body Report, United States - Measures Affecting the Cross-Border Supply of Gambling and Betting Services, WT/DS285/AB/R, adopted April 20, 2005.

Appellate Body Report, Dominican Republic - Measures Affecting the Importation and Internal Sales of Cigarettes, WT/DS302/AB/R, adopted May 19, 2005.

Panel Report, Brazil - Measures Affecting Imports of Retreated Tyres, WT/DS332/R, Appellate Body Report, WT/ DS332/AB/R, adopted December 17, 2007.

Appellate Body Report, United States - Mesures Affecting the Production and Sale of Clove Cigarettes, W'T/DS406/ AB/R, Adopted April 24, 2012.

Appellate Body Report, United States - Measures Concerning the Importation, Marketing and Sale of Tuna and Tuna Products,), WT/DS361/AB/R, Adopted June 13, 2012.

\section{Arbitral Awards}

SD Myers v Canada, First Partial Award, November 13, 2000, ICSID Reports, vol.8, p.18

Pope and Talbot v. Canada, Award on the Merits of Phase 2, April 10, 2001, ICSID Reports, vol.7, p.102.

Marvin Roy Feldman v. Mexico, Award, December 16, 2002, ICSID Reports, vol.7, p.341.

ADF v. United States, Award, January 9, 2003.

Occidental v. Ecuador, Award, July 1, 2004, ICSID Reports, vol.12, p.156.

Methanex v United States, Award, August 3, 2005, ILM, vol.44, p.1345.

GAMI v Mexico, Award, November 15, 2005, ICSID Report, vol.13, p.147.

Archer Daniels Midland v. Mexico, Award, November 21, 2007.

Corn Products v. Mexico, Decision on responsibility, January 15, 2008. 
Para publicar na Revista de Direito Internacional, acesse o endereço eletrônico www.rdi.uniceub.br ou www.brazilianjournal.org.

Observe as normas de publicação, para facilitar e agilizar o trabalho de edição. 